\title{
Stability of Urban Forms and Resilience of a System: The Case of Pre-Modern Parisian Street Network
}

\section{Stabilité des formes urbaines et résilience d'un système : Le cas du réseau viaire parisien pré-moderne}

\author{
Léa HERMENAULT ${ }^{1}$ \\ ${ }^{1}$ Post-doctoral Researcher at the Universiteit van Amsterdam / UMR 7041 ArScAn, "Archéologies environnementales" \\ research group, lea.hermenault@gmail.com
}

RÉSUMÉ. Dans cet article, je souhaite montrer combien il peut être heuristique de rester proche du concept de résilience tel qu'il a été défini par $\mathrm{C}$. S. Holling, lorsque l'on souhaite comprendre la complexité de l'évolution des paysages urbains. Pour ce faire, j'étudie ici le cas du réseau de rues parisiennes durant l'époque médiévale et moderne. Je montre dans quelle mesure ce réseau reste stable sur le long terme tout comme l'est le type d'activités que l'on pratique dans ces rues, alors que dans le même temps, les changements sont très fréquents à l'échelle des bâtiments. Cet apparent paradoxe s'explique par de complexes interactions que le concept de résilience peut aider à explorer. Je montre en effet dans la dernière partie de cet article que chercher le système résilient, qui aboutit à la stabilité du réseau de rues parisien, aide à comprendre quels sont les mécanismes socio-économiques qui sont à l'origine des observations réalisées. Je pose ainsi l'hypothèse que la stabilité du réseau viaire parisien est, entre autres, une conséquence de la résilience du système productif et commercial aux périodes médiévale et moderne : le client achète les produits qu'il souhaite au boutiquier, qui est très souvent impliqué dans leur fabrication et qui peut donc adapter sa marchandise aux désirs des clients. Les rues sont les lieux des échanges commerciaux. Tant que ces deniers se déroulent de la même manière, le réseau des rues a de fortes chances de rester stable.

ABSTRACT. In this paper, my aim is to show how edifying it can be to adhere to the concept of resilience proffered by C. S. Holling in order to better understand the complexity in which urban environments evolve. To do so, I study here the example of the Parisian street network during the Medieval and Early Modern periods. I show to what extent this network as well as the type of shops along certain streets remained stable over the long term, while also demonstrating that changes were indeed very frequent when one considers the buildings themselves. This apparent paradox can be explained by complex interactions that resilience can help to explore. I show in the third part of this paper that identifying the system of resiliency that produces stability in the Parisian street network leads to an understanding of the socio-economic mechanisms behind the observations made at different levels.

MOTS-CLÉS. Multiscalaire, Paris, Résilience, Rues, Systèmes complexes.

KEYWORDS. Multi-Scale, Paris, Resilience, Streets, Complex systems.

\section{Introduction}

According to C. S. Holling, resilience is the capacity of a social-ecological system to absorb or withstand perturbations and other stressors such that the system remains within the same regime, essentially maintaining its structure and functions. It describes the degree to which a system is capable of selforganization, learning and adaptation (Holling, 1973; Gunderson \& Holling, 2002 ; Walker et al., 2004, Resilience Alliance, 2019). Cities are systems which are considered as self-organized ${ }^{1}$. In this paper, I explain how resilience can increase our understanding of the complex evolution of urban landscapes.

\footnotetext{
${ }^{1}$ The self-organization of landscape elements has been studied in geography, in morphology and, during the past years, more specifically in archaeo-geography: see for instance Marchand (2003), Robert (2003 ; in press), or Clémençon \& Noizet (in press).
} 
For this purpose, I will focus on the city of Paris and the evolution of its urban fabric at two different scale during the Medieval and Early Modern periods. First I will show to what extent we can speak about the stability of the street network over the longue durée and the type of shops that existed along certain streets (macro scale). Secondly, I will show that the rate of change was significantly different for the buildings located along those same streets (micro scale). In the third part of this paper, I will explain that what first appears to be a paradox is actually not, and indeed reveals a complex system of resilience (Hermenault, $2017)^{2}$.

\section{Stability of the Parisian street network and functions over the longue durée}

This study compared two maps of the city of Paris to study the evolution of the street network over the long term. The first is a reconstitution of the late $14^{\text {th }}$ century Parisian street network by the CNRS based on written sources. The second is the Plan de Verniquet, engraved in 1791, and recognized for its high degree of street precision. If we compare these maps via an analytic grid composed of $25 \times 25 \mathrm{~m}$ squares, the result is figure 1, focused on the $14^{\text {th }}$ century city area. Each square is coloured depending on the presence or absence of differences between the $14^{\text {th }}$ and $18^{\text {th }}$ centuries: blue if no change is observed, black if a part of a medieval street disappeared, and yellow if a part of a street showed up in the late $18^{\text {th }}$ century but did not exist in the late $14^{\text {th }}$. A large majority of squares are blue ( $95 \%$ within the city walls), meaning that the major part of the medieval network was still in existence in the late $18^{\text {th }}$ century. We can thus conclude from figure 1 that the Parisian street network was very stable between the $14^{\text {th }}$ and $18^{\text {th }}$ centuries.

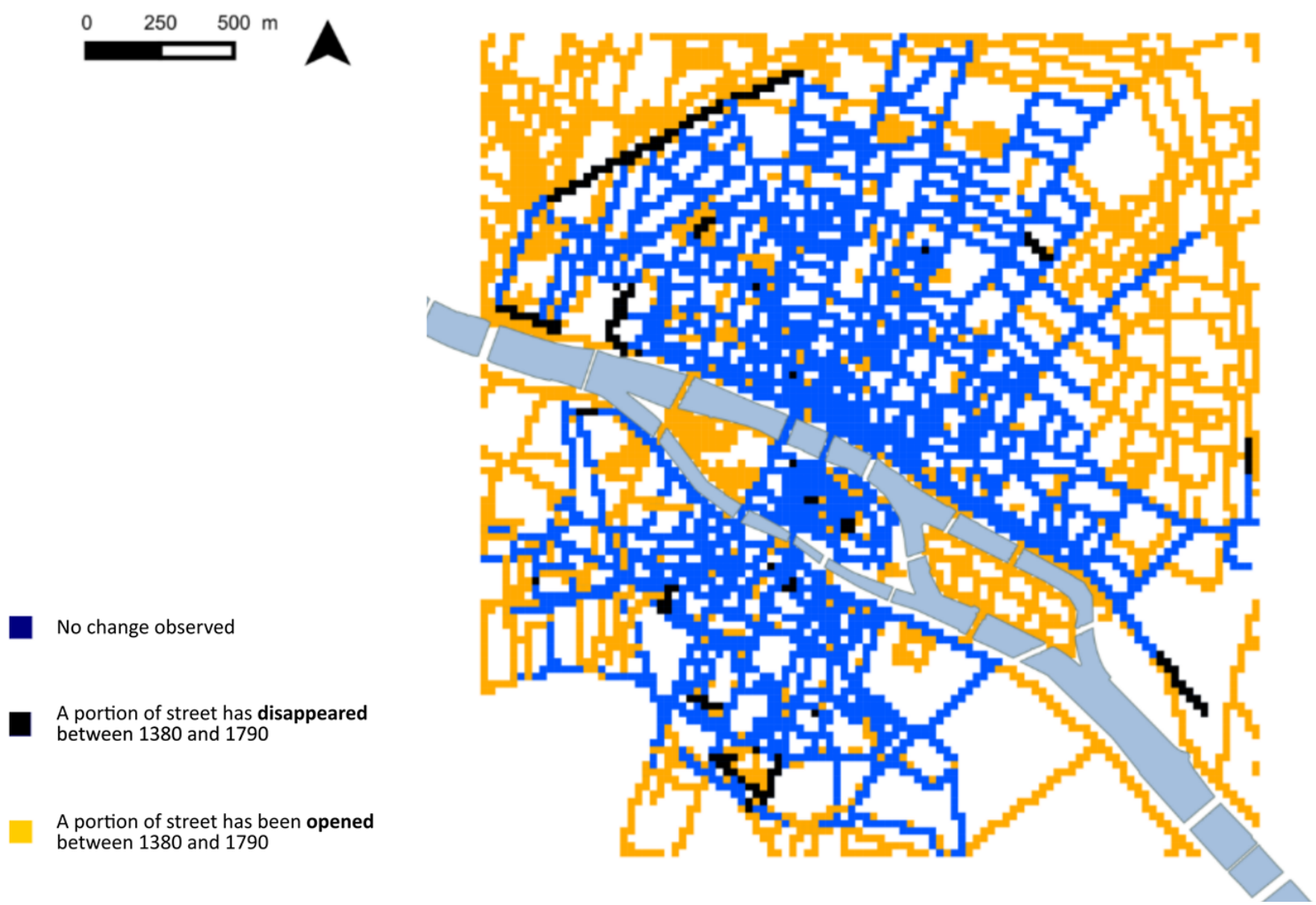

Figure 1. Comparison of two maps (1380 and 1791) of the Parisian street network through an analysis grid (squares of $25 \times 25 \mathrm{~m}$ ). (c) Léa Hermenault

\footnotetext{
${ }^{2}$ This study has first been elaborated in the context of my archaeology thesis: "La ville en mouvements. Circulations, échanges commerciaux et matérialité de la ville : pour une articulation systémique des facteurs d'évolution du tissu urbain parisien entre le XVe et le XIXe siècle“, Paris 1 Panthéon-Sorbonne University. This thesis, defended on the $17^{\text {th }}$ of April 2017, is available at this address: https://halshs.archives-ouvertes.fr/tel-01551802
} 
While the street network appears very stable, what about the occupations of people who were living along them? Studying the location of trades in Paris over the long term is possible based on three documents. The first, called les rôles de la taille, is a set of taxation registers studied by Caroline Bourlet (Bourlet \& Layec, 2013). Seven of these registers remain from the reign of King Philippe Le Bel. They are dated between 1292 and 1313, but only that of 1300 is complete. The purpose of these registers changed through time. The 1300 register, for example, is linked to a certain commercial tax, called maltôte, which was considered particularly restrictive and disadvantageous by Parisians. They managed to have it transformed into an annual payment based on property assets, or on furniture for the poorest. The register from 1300 corresponds to the last of these annual payments. It includes around 10,000 named taxpayers, their individual tax amount owed and, for about $75 \%$ of the entries, the individual's occupation. Each taxpayer can be precisely located within the city because tax collection was carried out along a route which is described in the register. For all these reasons, this taxation register holds a keen interest from a social-topography perspective (Bourlet \& Layec, 2013). For the purposes of this paper, I will focus on three occupations: bakers, pasty makers and hotel keepers. I have chosen these specific businesses because all of them are customer-flow dependent, and are thus good markers of the most visited streets in 1300. Figure 2 shows the location of these types of businesses across the city.

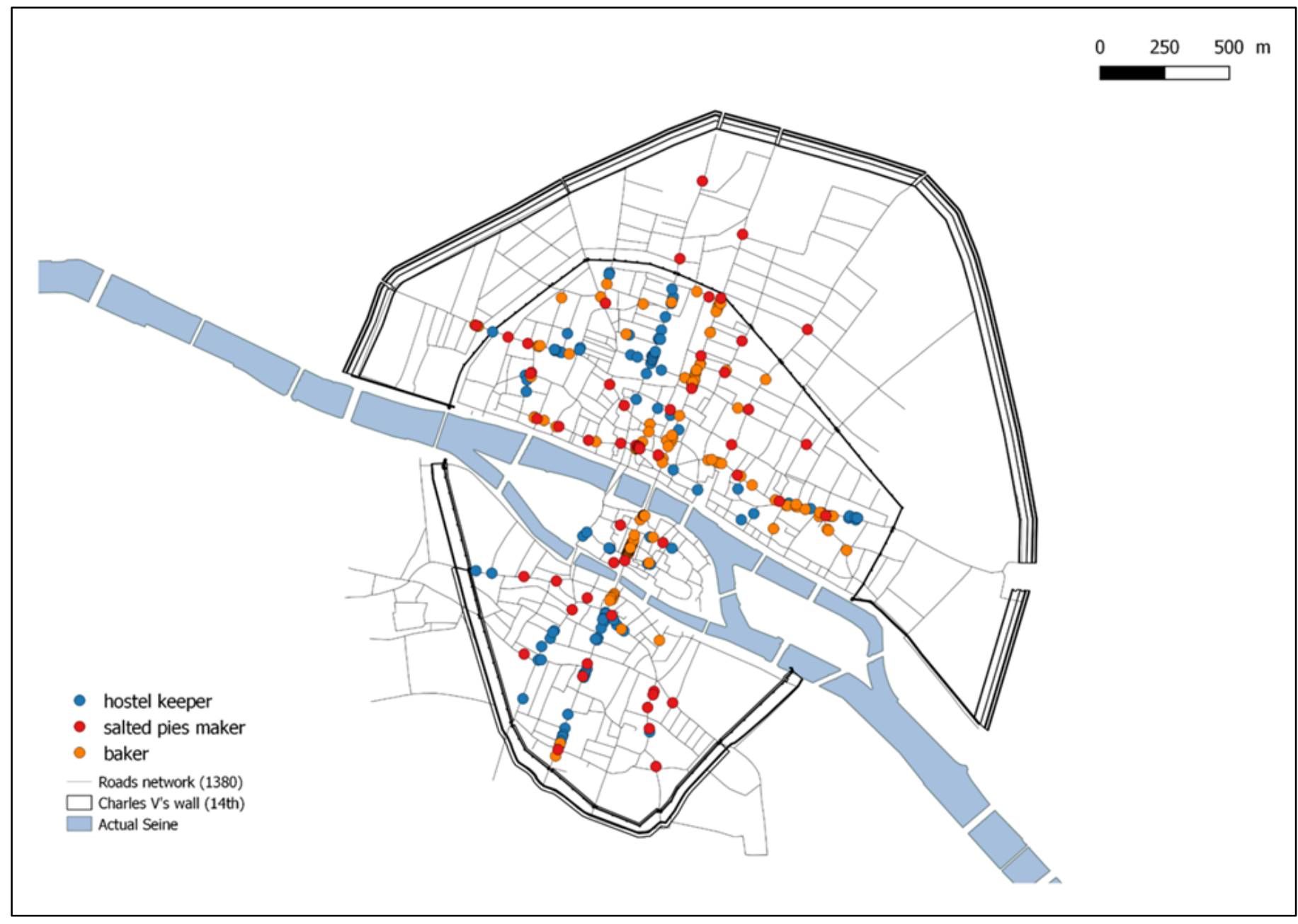

Figure 2. Location of bakers, hotel keepers and pasty makers in Paris in 1300 (study of the tax register "rôle de la Taille") - APUR @ ALPAGE : Anne-Laure Bethe, Caroline Bourlet, Yoann Brault, Nicolas Faucherre, Davide Gherdevich, Hélène Noizet - Léa Hermenault, 2019

I compared this data with the paving expenditures made by Paris merchants during the $15^{\text {th }}$ century. At the end of the $12^{\text {th }}$ century, King Philippe Auguste ordered every street of the city to be paved at the residents' expense, with the exception of certain streets whose paving was to be funded by a community of Paris merchants whose role was to organize and ensure trade in the city. These streets are very likely to have been those whose viability was considered vital for the city's supply of goods. They form what is called in 
the documents since at least the $14^{\text {th }}$ century la Croisée de Paris (the crossroads of Paris). The Croisée was composed of 23 streets in 1400 and 74 in 1489, meaning that streets were added to the group over time. All amounts paid by the merchant community for the paving or repaving of these streets were recorded each year in the Compte du domaine de la ville, together with other expenditures and receipts. None of these original account registers remain for the Middle Ages with the exception of 1488-1489, but copies of some of them were made in the mid-18th century, before the destruction of the originals in the late $18^{\text {th }}$ century. Twenty-five years of copied account registers between 1424-1489 are kept in the National Archives (registers published in Vidier et al., 1948 and Monicat, 1958). In total, 137 Parisian pounds were spent to repave 418 toises during these 25 years. It is worth noting that most of the streets included in the Croisée de Paris as of the $15^{\text {th }}$ century were already part of it as of the early $14^{\text {th }}$ century. We assume that the necessity of repaving a street can be linked to the circulation of pedestrians, livestock and vehicles, and thus can be a means of measuring human presence and use. If we compare data extracted from the tax register and paving expenditures, we can see that the streets which were attractive for flow-dependent trades in 1300 are the same as those most frequently repaved during the $15^{\text {th }}$ century (figure 3 ). A brief study of the shopkeeper map in the beginning of the $18^{\text {th }}$ century, made thanks to the data extracted from the Terrier $d u R o i^{3}$, leads to the conclusion that the most frequently repaved streets during the $15^{\text {th }}$ century are among those still used most frequently for shopping three centuries later (figure 4).

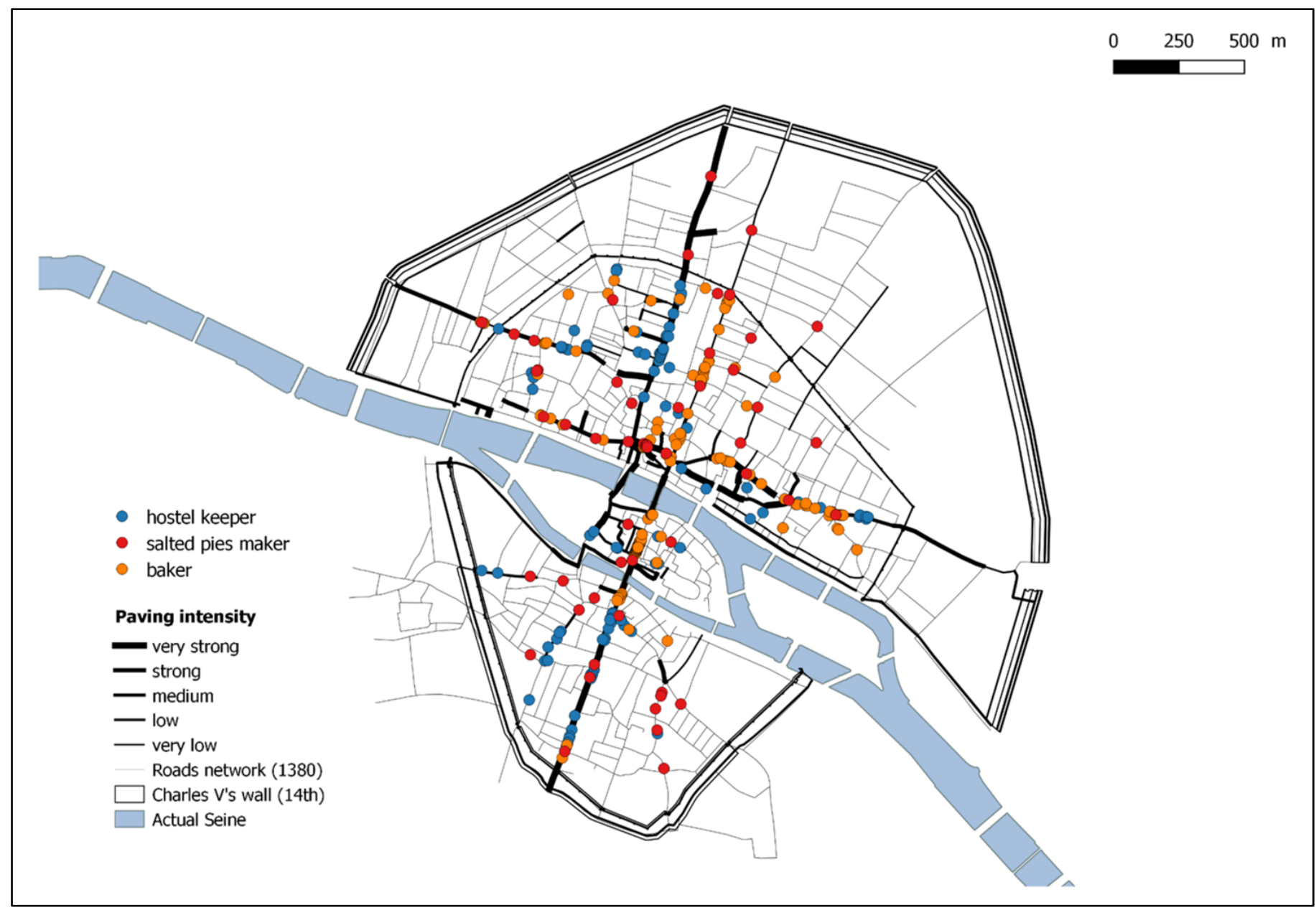

Figure 3. Comparison of the distribution of bakers, hotel keepers and pasty makers in Paris in 1300 (study of the tax register "rôle de la Taille") and of the repaving activities during the 15th century - APUR @ ALPAGE : Anne-Laure Bethe, Caroline Bourlet, Yoann Brault, Nicolas Faucherre, Davide Gherdevich, Léa Hermenault, Hélène Noizet - Léa Hermenault, 2019

\footnotetext{
${ }^{3}$ The Terrier du roi is composed of several registers (Archives Nationales, $Q^{1 *} 1099^{1-14}$ ), which aimed to describe plots of Paris (presence of shop, garden, buildings, etc.). Ordered in 1700, the project stopped in 1725 and remained uncomplete for the left riverbank of the city (Le Maresquier-Kesteloot, 2002).
} 


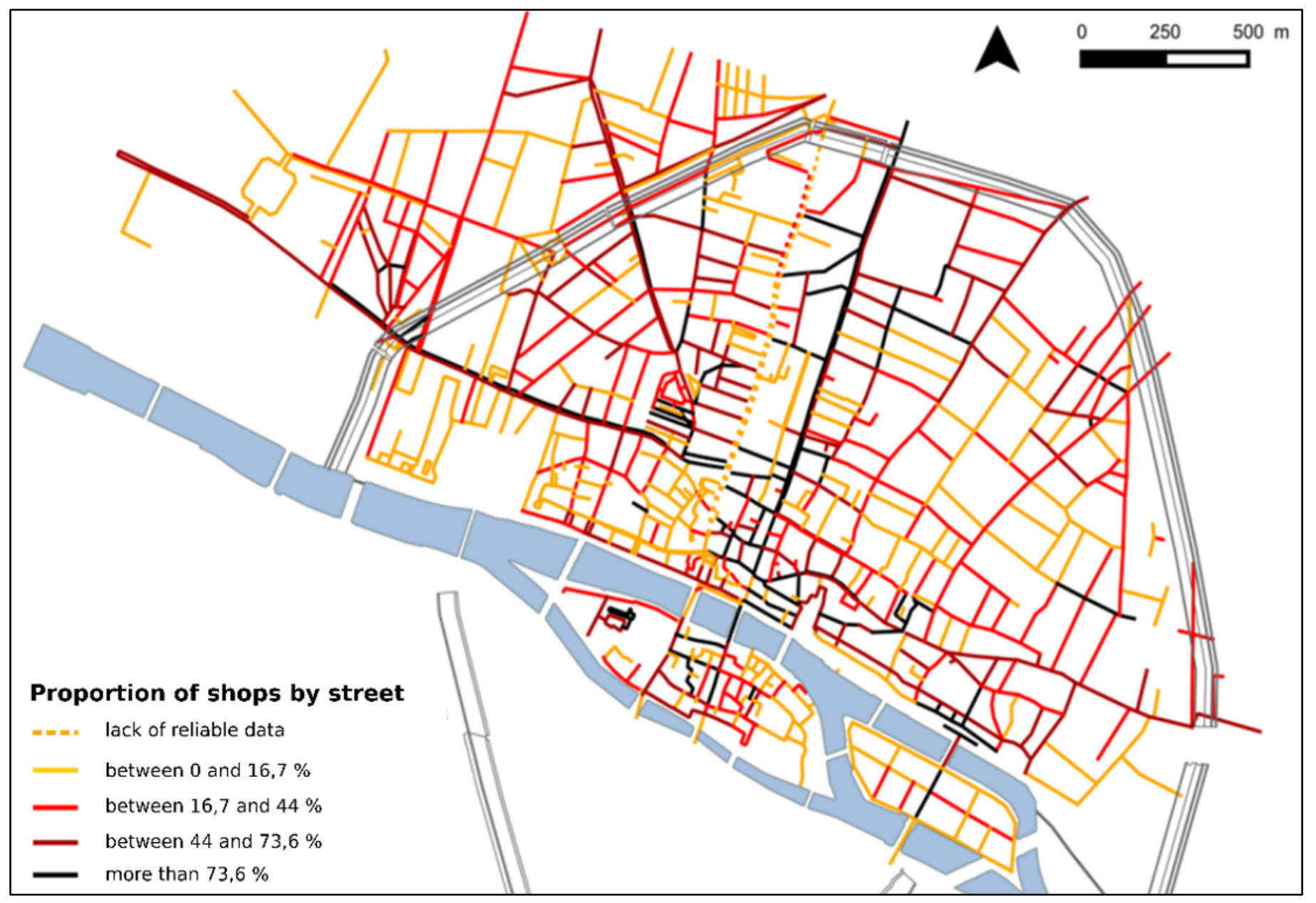

Figure 4. Proportion of parcels with shop(s) to total number of parcels in the beginning of the 18th century (study of the "Terrier du Roi") - APUR @ ALPAGE : Anne-Laure Bethe, Yoann Brault, Nicolas Faucherre, Davide Gherdevich, Léa Hermenault, Hélène Noizet - Léa Hermenault, 2015

At the city scale, we can thus witness the great stability of the Parisian street network and the continued attractiveness of several specific streets for shopkeepers between the $14^{\text {th }}$ and $18^{\text {th }}$ centuries. However do urban forms give the same impression of stability if we observe them on a larger scale?

\section{Parcels and buildings evolve at a different pace}

It is very difficult to get a complete overview of the evolution of a building block over the long term since, unfortunately, there are very few cities where archaeologists have managed to completely excavate an entire block. To fill this gap, I chose to use land parcels as a reflection of how buildings were organised: consolidating and splitting parcels and the evolution of circulation within city blocks can tell us much about the evolution of the buildings themselves. In Paris, several land transaction or planimetric documents enable us to follow the pace of evolution of land parcels over the long term, and therefore to deduce information about the evolution of buildings. I focused on the Place Maubert, one of the liveliest neighbourhoods on the left bank of the Seine river. Located at the foot of Montagne Sainte-Geneviève, Place Maubert received flows of passers-by and customers coming from both gates of Saint-Victor and Bordelle, meaning all the flows coming from the southeast of Paris. As proof of the high density of these flows, Place Maubert was one of the very few places on the left bank whose paving expenses were charged to the merchants of Paris in the late $15^{\text {th }}$ century. Figure 5 presents the evolution of two buildings blocks located along the Place Maubert between 1360 and 1460, known from work carried out by Anne Cauquetoux (Cauquetoux, 1986), who studied land management documents from the Sainte-Geneviève Abbey, the main landholder of the 
area. She reconstructed parcels located around the Place Maubert in 1360 and 1460. If we compare these two reconstitutions we note that several parcels were split along the Place Maubert and the Rue des Noyers (red), and approximately 20 were consolidated along the side streets Rue des Lavandières and Rue des Anglais (blue). The consequences of these changes upon circulation within the blocks are important: new easements were created and some tenants took advantage of the consolidation of parcels to increase the number of access points, for example obtaining one on the main street for customer purposes and another on a side street to facilitate vehicle entry. These two reconstitutions clearly show that there were a multitude of changes to parcel configurations between 1360 and 1460, and it is logical to assume that buildings must have undergone numerous modifications.
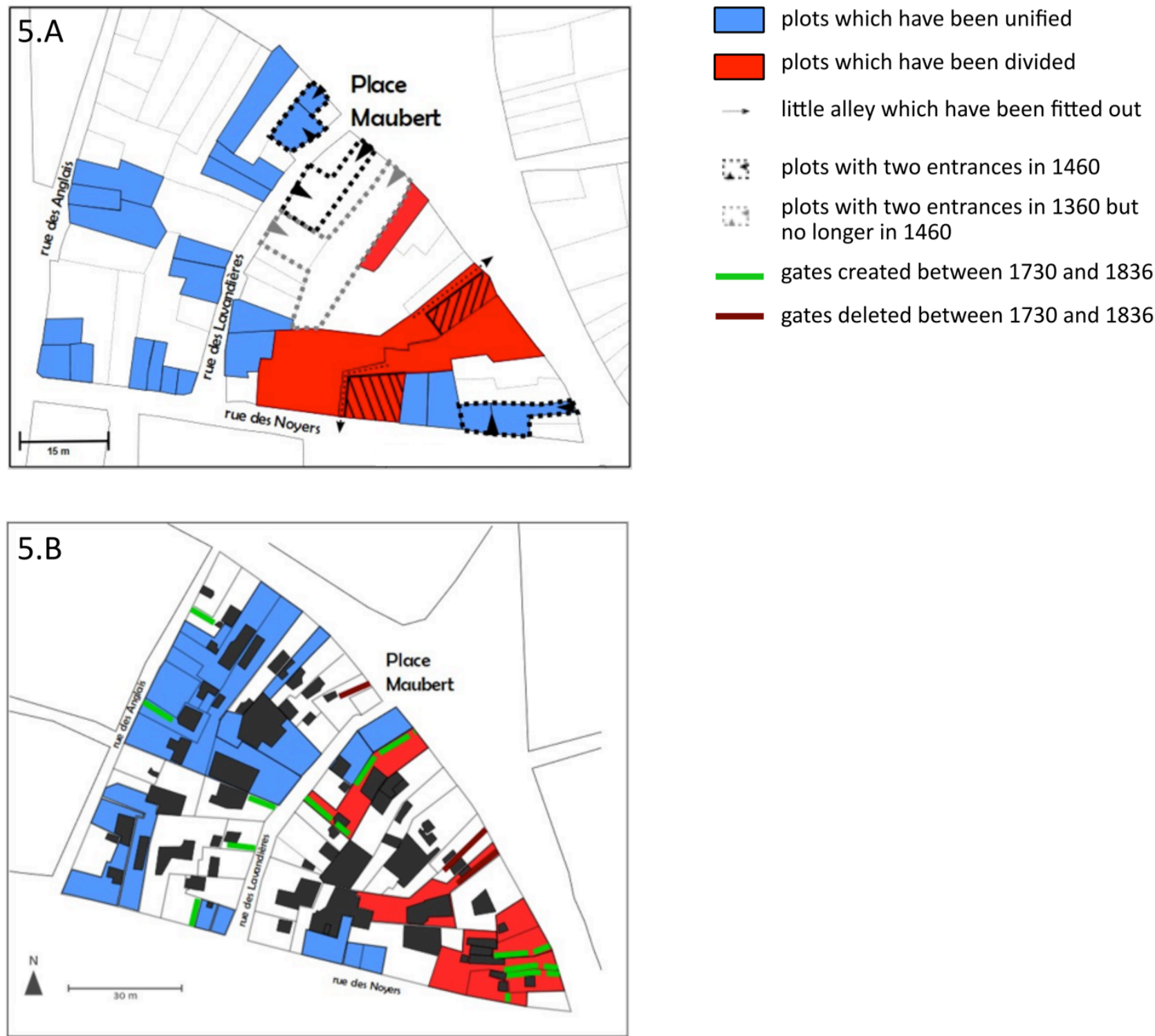

Figure 5. Evolution of two building blocks during two time periods (5.A: 1360-1460; 5.B: 1730-1836). (C) Léa Hermenault, d'après Anne Cauquetoux, 1986

The comparison of two more parcel representations shows the evolution of parcel limits during another time period. The first of them is a local cadastral map likely drawn by Abbot Delagrive. Entitled Plan détaillé de la place Maubert ${ }^{4}$, it is dated around 1730. The second are the oldest and most complete cadastral

\footnotetext{
${ }^{4}$ Boutier, Sarazin and Sibille, 2007, pp. 277-279 (Bibliothèque Nationale de France, RESERVE VE-53 (J)-FT 6) is available online: http://catalogue.bnf.fr/ark:/12148/cb40312686w.public
} 
maps in existence for Paris. Called plans Vasserot, they were drawn by Philibert Vasserot and his colleagues between 1810 and $1836^{5}$. Figure 5 shows the evolution of the same two building blocks between 1730 and 1836. Numerous parcel consolidations can be observed along the Rue des Noyers, at the corner of Place Maubert and Rue des Lavandières and in the northern sector of the block. Consolidations were at times part of large developments in certain areas (eg. close to Rue des Anglais), but could also be more limited in scope (eg. Rue des Noyers). Parcels were split in the southwest corner of the block edged by Rue des Noyers and Rue des Anglais, but also around the tip of the block edged by Place Maubert and Rue des Noyers. In addition, many main entrance gates had disappeared along Rue des Noyers and Place Maubert, while several others opened along different streets. We can assume that much of a building block's internal circulation was altered due to the addition or removal of a main gate.

From figure 5 we may conclude that land parcels underwent a high degree of evolution during the two periods studied. There is therefore a very high probability that the organisation of buildings was also significantly modified during that time.

\section{Stability versus speed: the contribution of "resilience"}

Previous examples have shown how the urban fabric can significantly change at the micro scale over the long term even if, in the identical time period, almost no changes can be observed at the macro scale. What may at first appear to be a paradox is actually not. This is because buildings evolve at a different pace than street networks, which may remain stable: every slight modification carried out on the scale of buildings reinforces the limits of the street, and the street network is consistently strengthened because building modifications are not taking place simultaneously.

I argue that the pace of building evolution, especially in the Quartier Maubert, is the consequence of the attractiveness of streets over the long term. The crucial position of the Place Maubert crossroads in the Parisian network explains its attractiveness for shopkeepers. Constant splitting and consolidation of parcels, in addition to the fragmented characteristics of the latter, along the most travelled streets ${ }^{6}$ was surely the result of the attractiveness of this neighbourhood, notably for shopkeepers.

In my view, the stability of the Parisian street network, as well as the stable functional orientation of several roads, can be explained in part by the attractiveness of streets as spaces of commercial interactions: because the streets remained particularly attractive for shopkeepers, they continued to locate their trades there. Thus, the constant evolution of the buildings ensured the stability of the streets themselves ${ }^{7}$.

I would argue that the permanence of the network during late Medieval and Early Modern period is a consequence of the resilience of a specific productive and commercial system: customers bought products from shopkeepers, who most of the time were also the producers of such products. Under this system, the streets were places of exchange. As long as commercial exchanges play out in the same way, streets have higher chances of remaining stable, as do the trades practied there (see figure 6).

\footnotetext{
${ }^{5}$ Georeferenced and vectorized to the ANR funded research program ALPAGE (AnaLyse diachronique de l'espace urbain PArisien: approche GEomatique), led by Hélène Noizet. Data are available at this address: https://alpage.huma-num.frl (Noizet et al., 2013).

${ }^{6}$ This kind of pattern is typical of attractive areas (Boudon et al., $1977: 61$ ).

7 This kind of observation has already been made by archaeo-geographers in different contexts. For instance, Sandrine Robert (see her article in this journal issue - Robert, 2021 - this issue) shows in what extent the stability of routes (macro scale) over the longue durée in strongly linked to street network's possibilities of transformations (micro scale).
} 
This productive and commercial system was resilient because each of its components was capable of adaptation: the craftsman/shopkeeper for instance was able to develop his or her production according to customers' desires or fashion trends just by returning to their workshop located in the back of the shop. This kind of cycle could be very short (days or weeks), but cycles grew increasingly longer once the productive system began evolving and the place of production began moving further away from the place of sale. This kind of change become increasingly frequent and notable in Paris from the $18^{\text {th }}$ century with the so-called "shopping revolution" (Blondé \& Coquery, 2005), and then in the beginning of the $19^{\text {th }}$ century with the Industrial Revolution. The evolution of the productive and commercial system and its relation with the evolution of the urban fabric could be the next step of this line of research.

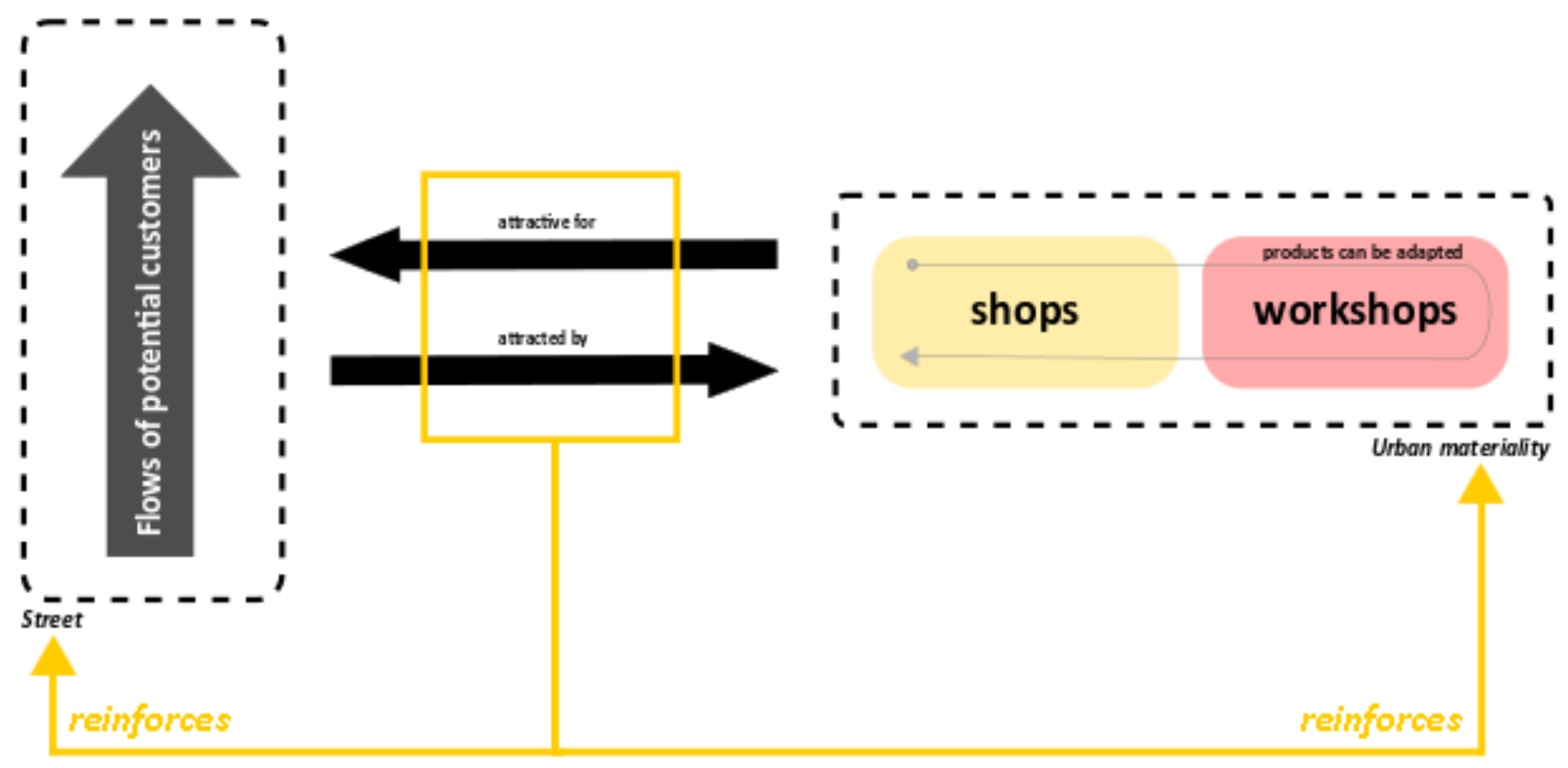

Figure 6. Diagram of the productive and commercial system and its interactions with the urban fabric (c) Léa Hermenault

\section{Conclusion}

In the first part of this paper I have shown how stable the Parisian street network remained between the $14^{\text {th }}$ and $18^{\text {th }}$ centuries and how constantly well-travelled and therefore attractive several specific streets proved for shopkeepers in that period. However, it would be simplistic to conclude that the Parisian street network was resilient over the long term, because the word resilience, as defined by C. S. Holling, describes the evolution of a system, not of a unique structure. I conclude that the stability of the Parisian street network nonetheless results from the resilience of a system.

A study conducted on the building scale helps us to understand more of this system. A two-period study of a very lively Parisian neighbourhood demonstrated that parcels, and probably therefore also buildings, are constantly subject to reorganisation. I have assumed that this dynamic is the sign of the attractiveness of certain streets of this neighbourhood for residents and more specifically for shopkeepers: a crowded place is attractive for merchants and, thanks to a high density of shops, also attractive for customers. They buy their products from shopkeepers, who can easily adapt their goods or their production to customer demand. As long as commercial exchanges proceed in this manner, streets have a higher probability of remaining stable because they are the central location of such exchanges.

Thus, it's partly because the productive and commercial system is resilient over the longue durée (that means that it can absorb or withstand perturbations that occurred at micro scale) that the material structure of 
this system (street network, density of buildings) remains the same. Perturbations are therefore one condition of this material structure's stability. At a micro scale, we can also assume that some charasteritics of this material structure (plots fragmentation for instance) are one condition of the occurrence of such numerous perturbations. The evolution of the system once consumption patterns change is yet to be analysed.

Employing the concept of "resilience" according to the enriched definition proffered by C. S. Holling allows for a better exploration of the social reality of past societies. Used in this manner, it shows to what extent resilience is not only relevant to describing complex systems, but also a powerful heuristic tool.

REMARK. This text is published following its presentation at the session organized by the commission Theory and methods in Landscape archaeology - Archeogeography at the XVIII ${ }^{\text {th }}$ Congress of the International Union of Prehistoric and Protohistoric Sciences (UISPP), Tuesday, June 5, 2018 at the University Paris 1 PanthéonSorbonne. The UISPP, founded in 1931, is a member of the International Council for Philosophy and Humanistic Studies, and is associated with UNESCO and the International Academic Union (https://www.uispp.org/).

REMARQUE. Ce texte est publié suite à sa présentation dans la session organisée par la commission Theory and methods in Landscape archaeology - Archeogeography lors du XVIII ${ }^{\mathrm{e}}$ Congrès de l'Union Internationale des Sciences Préhistoriques et Protohistoriques (UISPP), le mardi 5 juin 2018 à l'Université Paris 1 PanthéonSorbonne. L’UISPP, fondée en 1931, est membre du Conseil International de philosophie et de sciences humaines, et associée à l'UNESCO et à l'Union Académique Internationale (https://www.uispp.org/).

\section{Acknowledgements}

I would like to express my gratitude to the UISPP and especially to the Landscape Commission led by Sandrine Robert for having given me the occasion to present this paper during the XVIII ${ }^{\text {th }}$ Congress and to publish it. I also would like to thanks Stéphanie Cooper-Slockyj for her revision of the English version of this text.

\section{Conflicts of interest}

No conflict of interest to declare.

\section{Evaluation}

Reviewer for this paper is Michelle Elliott.

\section{Peer-reviewer responsibilities}

Reviewer evaluations are given serious consideration by the editors and authors in the preparation of manuscripts for publication. Nonetheless, being named as a reviewer does not necessarily denote approval of a manuscript; the editors of Archaeology, Society and Environment take full responsibility for final acceptance and publication of an article.

\section{Bibliographical references}

Blondé, B., Coquery, N., 2005. Retailers and Consumer Changes in Early Modern Europe: England, France, Italy and the Low Countries. Presses universitaires François-Rabelais, Tours, 259 p.

Boudon, F., Chastel, A., Couzy, H., Hamon, F., 1977. Système de l'architecture urbaine: le quartier des Halles à Paris. Editions du Centre National de la Recherche Scientifique, Paris, 414 p.

Bourlet, C., Layec, A., 2013. Densités de population et socio-topographie : la géolocalisation du rôle de taille de 1300, in: Noizet, H., Bove, B., Costa, L. (Eds), Paris, de parcelles en pixels. Presses universitaires de Vincennes et Comité d'histoire de Paris, Saint-Denis, Paris, 223-245. 
Boutier, J., Sarazin J-Y., Sibille, M. 2007. Les plans de Paris: des origines (1493) à la fin du XVIII siècle. Bibliothèque nationale de France, Paris, $430 \mathrm{p}$.

Cauquetoux, A., 1986. Le quartier Maubert (place Maubert, rues Galande, des Noyers et des Anglais), aux XIV et $X V^{e}$ siècle. Mémoire de maîtrise, Université Paris 4, Paris, 95 p.

Clémençon, A-S, Noizet, R., sous presse (2021). Faire ville. Entre planifié et impensé, la fabrique ordinaire des formes urbaines. Presses universitaires de Vincennes, Saint-Denis, $464 \mathrm{p}$.

Gunderson, L., H., Holling, C. S., 2002. Panarchy: Understanding Transformations in Systems of Humans and Nature. Island Press, Washington DC, 536 p.

Hermenault, L., 2017. La ville en mouvements. Circulations, échanges commerciaux et matérialité de la ville : pour une articulation systémique des facteurs d'évolution du tissu urbain parisien entre le XV et le XIX siècle. Thèse de Doctorat, Université Paris 1 Panthéon-Sorbonne, Paris, 611 p.

Holling, C. S., 1973. Resilience and stability of ecological systems. Annual Review of Ecology and Systematics. 4(1), $1-23$.

Le Maresquier-Kesteloot, Y-H., 2002. Le terrier du Roi pour la ville et faubourgs de Paris au début du XVIII siècle, in : Brunel, G., Guyotjeannin, O., Moriceau, J.-M. (Éds), Terriers et plans-terriers. Actes du colloque de Paris (2325 septembre 1998), Ecole nationale des Chartes, Paris, 133-150.

Marchand, C., 2003. Des centuriations plus belles que jamais ? Etudes rurales. 167-168, 93-113.

Monicat, J., 1958. Comptes du domaine de la Ville de Paris (1457-1489). Imprimerie Nationale, Paris, 699 p.

Noizet, H., Bove, B., Costa, L., 2013. Paris, de parcelles en pixels. Presses universitaires de Vincennes et Comité d'histoire de Paris, Saint-Denis, Paris, 243 p.

Resilience Alliance, 2019. Key Concepts. https://www.resalliance.org/key-concepts, visited on the $18^{\text {th }}$ of November 2019

Robert, S., 2003. L'analyse morphologique des paysages entre archéologie, urbanisme et aménagement du territoire : exemples d'études de formes urbaines et rurales dans le Val-d'Oise. Thèse de Doctorat, Université Paris 1 Panthéon-Sorbonne, Paris, 1391 p.

Robert, S., 2021. Applying the concept of panarchy in archaeogeography: the example of resilience of routes in the "longue durée". Archéologie, société et environnement. 2(1), ce volume.

Robert, S., sous presse. La résilience : persistance et changement dans les formes du paysage. ISTE, Londres, $286 \mathrm{p}$.

Vidier, A., Le Grand, L., Dupieux, P., 1948. Comptes du domaine de la Ville de Paris (1424-1456). Imprimerie Nationale, Paris, 1055 p.

Walker, B., Holling C. S., Carpenter, S. R., Kinzig, A., 2004. Adaptability and Transformability in Social-Ecological Systems. Ecology and Society. 9(2), 5. 